\title{
Spontaneous corneal perforation in an eye with Peters' anomaly
}

This article was published in the following Dove Press journal:

Clinical Ophthalmology

26 July 2013

Number of times this article has been viewed

\section{Moosang Kim \\ Seung-Chan Lee \\ Seung-Jun Lee}

Department of Ophthalmology, School of Medicine, Kangwon

National University, Chuncheon, South Korea
Correspondence: Seung-Jun Lee Department of Ophthalmology, Hospital 200-722, School of Medicine, Kangwon National University, Baengnyeong-ro I56, Chuncheon-Si, Gangwon-Do Kangwon National University Chuncheon, South Korea

Tel +82 332582014

Fax +82 22582191

Email ophkimmoo@gmail.com

\begin{abstract}
A premature female infant underwent her first ophthalmologic examination at the age of 4 weeks. The initial examination of the baby was requested for evaluation of a 'white spot' on the surface of her right eye. She had been hospitalized in the neonatal intensive care unit because of systemic abnormalities, such as a right clavicle fracture and microcephaly. Slit-lamp examination of the right eye showed a central corneal opacity, corneal thinning, and an iridocorneal adhesion. The lens and fundus of the right eye could not be observed. We observed no pathologic findings in the left eye. The baby's parents were informed of the high risk for spontaneous corneal perforation without external pressure. At 42 days of age, an ophthalmologic examination of the infant was again requested for evaluation of 'tears' from her right eye 3 hours previously. Examination revealed corneal perforation, iris protrusion, and a flat anterior chamber. We performed emergent conjunctival flap surgery. Three months following surgery, the patient's right eye was successfully preserved with no sign of inflammation or leakage.
\end{abstract}

Keywords: conjunctival flap, corneal perforation, Peters' anomaly

\section{Introduction}

Corneal perforation in the perinatal period is rare, and only a few cases are described in the literature. In most of the reported cases, low birth weight and systemic infection were associated with corneal perforation in the perinatal period, ${ }^{1-4}$ but there is one report of corneal perforation in relatively healthy newborns without evidence of trauma. ${ }^{5}$ Anterior segment dysgenesis, such as Peters anomaly, is also associated with corneal perforation. ${ }^{6-8}$ Peters' anomaly is characterized by a central corneal opacity from the time of birth and is accompanied by corresponding defects in the posterior stroma, Descemet's membrane, and endothelium. ${ }^{9,10}$ We report a case of spontaneous corneal perforation in a neonate with Peters' anomaly treated with a conjunctival flap.

\section{Case report}

A premature female infant, born after a gestational period of 33 weeks with a birth weight of $1.41 \mathrm{~kg}$, underwent her first ophthalmologic examination at 4 weeks of age. The initial examination of the baby was requested for evaluation of a 'white spot' on the surface of her right eye. She was hospitalized in the neonatal intensive care unit due to systemic abnormalities, such as a right clavicle fracture and microcephaly.

Slit-lamp examination of the right eye revealed a central corneal opacity, corneal thinning, and an iridocorneal adhesion (Figure 1). The iris was fused with the posterior surface of the peripheral cornea, with poor formation of the anterior chamber. The lens and fundus in the right eye could not be observed. A B-scan, however, showed a normal 


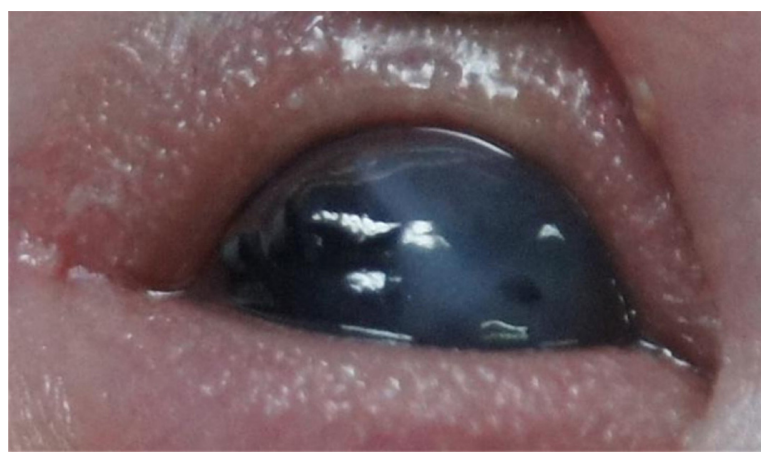

Figure I Initial anterior segment findings of the right eye. Central corneal opacity, corneal thinning, and iridocorneal adhesion were observed.

posterior segment. Intraocular pressure could not be measured due to severe corneal thinning. The left eye showed no pathologic findings. The parents were informed of the high risk of spontaneous corneal perforation without external pressure.

At 42 days of age, an ophthalmologic examination of the infant was again requested for evaluation of 'tears' from her right eye observed 3 hours previously. Examination revealed corneal perforation, iris protrusion, and a flat anterior chamber (Figure $2 \mathrm{~A}$ ). We performed a $360^{\circ}$ conjunctival peritomy (Figure 2B) under general anesthesia to create a conjunctival flap, and the flap was brought down to cover the cornea. Simple interrupted sutures with 8-0 Vicryl (Ethicon EndoSurgery, Inc, OH, USA) were then used to close the incision (Figure 2C and D). Three months after the surgery, the right eye of patient was successfully preserved, with no sign of inflammation or leakage.

\section{Discussion}

Since Peters' original description in $1906,{ }^{11}$ many others have reported the ocular abnormalities now known as

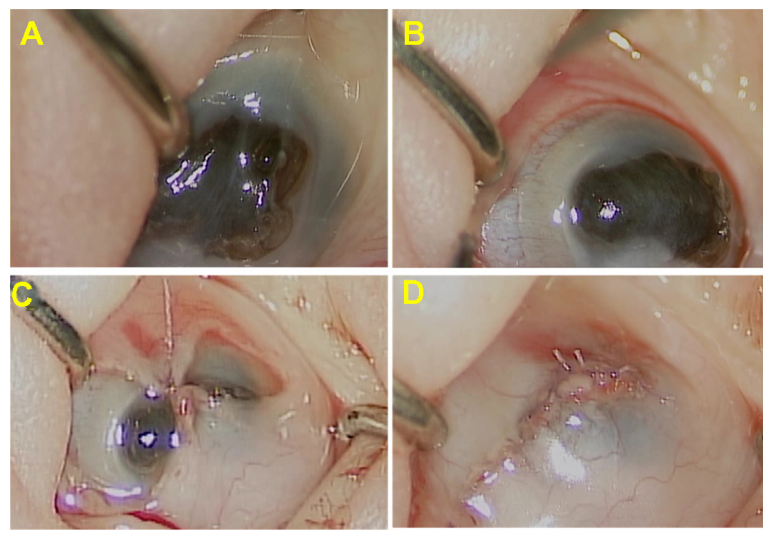

Figure 2 Intraoperative findings. Iris protrusion and a flat anterior chamber were observed.

Notes: (A) A $360^{\circ}$ peritomy was performed to increase the conjunctival mobility. (B) The flap was brought down to cover the cornea. Simple interrupted sutures with 8-0 Vicryl were used (C and $\mathbf{D})$.
Peters' anomaly. In 2007, Zaidman et al subdivided Peters' anomaly into 3 types: (Type I) central corneal opacity with iridocorneal adhesions; (Type II) central corneal opacity with cataracts or corneolenticular adhesions; and (Type III) Peters' anomaly in association with cleft lip/palate, short stature, abnormal ears, and mental retardation. ${ }^{12}$

Peters' anomaly may be isolated or accompanied by other ocular malformations such as chorioretinal coloboma, a congenital defect caused by faulty closure of the embryonic fissure, and is associated with other ocular and systemic abnormalities. $^{13}$

To our knowledge, however, only three reports of spontaneous corneal perforation occurring in association with Peters' anomaly have been reported in the literature. ${ }^{6-8}$ Krause et al reported the first case of Peters' syndrome with spontaneous corneal perforation in $1969 .{ }^{6}$ Traboulsi and Maumenee reported clinical findings in 29 patients with Peters' anomaly, and one of 29 patients developed spontaneous corneal perforation. ${ }^{7}$ Banning et al described two patients with corneal perforation and secondary congenital aphakia in Peters' anomaly. They performed penetrating keratoplasty to preserve the eyes. ${ }^{8}$ In our case, however, we had to create a conjunctival flap rather than perform penetrating keratoplasty because of the lack of a donor cornea.

The conjunctival flap is a well proven, time honored treatment for numerous disparate corneal diseases that have a persistently compromised ocular surface in common. ${ }^{14-16}$ The purpose of the conjunctival flap is to restore the integrity of a compromised corneal surface, typically damaged as a result of trauma, neurotrophic disease, severe dry eye, or bullous keratopathy. The flaps prevent progressive corneal ulceration and secondary infection; they also control pain, eliminate frequent medications, and improve cosmesis. Complications encountered after conjunctival flap surgery are relatively uncommon, but the most frequently reported complications include flap retraction, conjunctival buttonholes and erosions, epithelial inclusion cysts, and corneal perforations. ${ }^{17}$ In the present case, there were no complications. Although the conjunctival flap does not permit good visual acuity or good visualization of the anterior chamber details, it is sufficient to preserve the eye.

In our case, we did not perform genetic analyses. The $P A X 6$ gene, which is expressed in the developing central nervous system, including the eye, is vital to eye development and is influential at early stages of ocular morphogenesis, acting as a master control gene. ${ }^{18}$ It is therefore believed to play an important role in ocular embryogenesis. Mutations of the PAX6 gene are associated with various 
ocular anomalies, including Peters' anomaly, aniridia, and chorioretinal coloboma. ${ }^{19}$ Genetic studies of the patient may help to elucidate the causes of this anomaly.

\section{Conclusion}

Although rare, corneal perforation can occur in Peters' anomaly. To our knowledge, this is the first documented case of a spontaneous corneal perforation in Peters' anomaly treated with a conjunctival flap.

\section{Disclosure}

The authors report no conflicts of interest in this work.

\section{References}

1. Bachynski BN, Andreu R, Flynn JR. Spontaneous corneal perforation and extrusion of intraocular contents in premature infants. $J$ Pediatr Ophthalmol Strabismus. 1986;23:25-28.

2. Jensen OA. Necrotizing keratitis (keratomalacia) with corneal perforation and expulsive uveal hemorrhage in a new-born. Acta Ophthalmol (Copenhagen). 1968;46:215-217.

3. Backes CR, Makley TA Jr, Rogers GL, Cordero LC, Forsythe R. Spontaneous corneal perforation with expulsion of the lens and retina in a premature infant. J Pediatr Ophthalmol Strabismus. 1980;17: 242-244.

4. Michelson PE, Rupp R, Efthimiadis B. Endogenous Candida endophthalmitis leading to bilateral corneal perforation. $\mathrm{Am} \mathrm{J}$ Ophthalmol. 1975;80:800-803.

5. Zagelbaum BM, Stroh EM, Perry HD, Donnenfeld ED, Cossari AJ. Corneal perforation in a premature infant. J Refract Surg. 1995;11:96-98.

6. Krause U, Koivisto M, Rantakallio P. A case of Peters syndrome with spontaneous corneal perforation. J Pediatr Ophthalmol Strabismus. $1969 ; 6: 145-149$.
7. Traboulsi EI, Maumenee IH. Peters' anomaly and associated congenital malformations. Arch Ophthalmol. 1992;110:1739-1742.

8. Banning CS, Blackmon DM, Song CD, Grossniklaus HE. Corneal perforation with secondary congenital aphakia in Peters' anomaly. Cornea. 2005;24:118-120.

9. Nakanishi I, Brown SI. The histopathology and ultrastructure of congenital, central corneal opacity (Peters' anomaly). Am J Ophthalmol. 1971;72:801-812.

10. Waring GO 3rd, Rodrigues MM, Laibson PR. Anterior chamber cleavage syndrome. A stepladder classification. Surv Ophthalmol. 1975;20: $3-27$.

11. Peters A. Innate defect formation of Descemet's membrane. [Ueber angeborene Defektbildung der descemetschen Membran.] Klin Monatsbl Augenheilkd. 1906;44:27-40. German.

12. Zaidman GW, Flanigan JK, Furey CC. Long-term visual prognosis in children after corneal transplant surgery for Peters anomaly type I. Am J Ophthalmol. 2007;144:104-108.

13. Berk AT, Yaman A, Saatçi AO. Ocular and systemic findings associated with optic disc colobomas. J Pediatr Ophthalmol Strabismus. 2003;40:272-278.

14. Donzis PB, Mondino BJ. Management of noninfectious corneal ulcers. Surv Ophthalmol. 1987;32:94-110.

15. Portnoy SL, Insler MS, Kaufman HE. Surgical management of corneal ulceration and perforation. Surv Ophthalmol. 1989;34:47-58.

16. Brown DD, McCulley JP, Bowman RW, Halsted MH. The use of conjunctival flaps in the treatment of herpes keratouveitis. Cornea. 1992;11:44-46.

17. Alino AM, Perry HD, Kanellopoulos AJ, Donnenfeld ED, Rahn EK Conjunctival flaps. Ophthalmology. 1998;105:1120-1123.

18. Hanson IM, Fletcher JM, Jordan T, et al. Mutations at the PAX6 locus are found in heterogeneous anterior segment malformations including Peters' anomaly. Nat Genet. 1994;6:168-173.

19. Gregory-Evans CY, Williams MJ, Halford S, Gregory-Evans K. Ocular coloboma: a reassessment in the age of molecular neuroscience. $J$ Med Genet. 2004;41:881-891.
Clinical Ophthalmology

\section{Publish your work in this journal}

Clinical Ophthalmology is an international, peer-reviewed journal covering all subspecialties within ophthalmology. Key topics include: Optometry; Visual science; Pharmacology and drug therapy in eye diseases; Basic Sciences; Primary and Secondary eye care; Patient Safety and Quality of Care Improvements. This journal is indexed on

Submit your manuscript here: http://www.dovepress.com/clinical-ophthalmology-journal

\section{Dovepress}

PubMed Central and CAS, and is the official journal of The Society of Clinical Ophthalmology (SCO). The manuscript management system is completely online and includes a very quick and fair peer-review system, which is all easy to use. Visit http://www.dovepress.com/ testimonials.php to read real quotes from published authors. 